SBedergi, 2021; 5(9), 204-231

DOI: $10.29228 /$ sbe. 52431

E-ISSN: $2602-4306$

www.sbedergi.com

Geliş Tarihi (Received): 23.08.2021

Kabul Tarihi (Accepted): 01.12.2021

\title{
SAĞLIK KURUMLARINDA ALGILANAN \\ KURUMSAL İMAJIN DEĞERLENDİRİLMESİ: \\ BİR KAMU HASTANESİ ÖRNEĞİ 1
}

\author{
Süleyman AĞRAŞ ${ }^{2}$ \\ https://orcid.org/0000-0003-0999-0904 \\ Seda KAŞKIR ${ }^{3}$ \\ https://orcid.org/0000-0001-5422-0111
}

$\ddot{\mathbf{O z}}$

Kurumsal sürdürülebilirlik açısından imaj oluşturma çalışmaları bir tercihten çok zorunluluk halini almaktadır. Toplumda pozitif bir imaja sahip olmak isteyen kurumların kurumsal imaj çalışmalarını bilinçli ve sistemli bir şekilde yürütmesi oldukça önemlidir. Bu araştırmada, bir kamu hastanesinden sağlık hizmeti alan hasta ve hasta yakınlarının hastane ile ilgili imaj algılarının tespit edilmesi amaçlanmıştır. Literatür taranarak hazırlanan Kurumsal İmaj Anket Formu ile yüz yüze anket tekniği kullanılarak 384 sağlık hizmeti alıcısına ulaşılmıştır. 2020 yılı Şubat-Temmuz aylarında toplanan verilerin analizinde SPSS ve AMOS programları kullanılmıştır. Elde edilen verilere tanımlayıcı istatistikler, faktör analizleri, farklılık analizleri ve yapısal eşitlik modeli uygulanmıştır. Yapılan analiz ve değerlendirmeler ışığında sağlık kurumlarında algılanan kurumsal imaj; iletişim, fiziksel koşullar, kalite ve sosyal sorumluluk olmak üzere 4 boyutta ele alınabileceği tespit edilmiştir. Araştırma sonucunda katılımcıların kurumsal imaj faktörlerinden en çok kalite ve iletişim boyutlarını pozitif yönde algılandığı, fiziksel ve sosyal sorumluluk boyut algılarının daha düşük olduğu saptanmıştır. Katılımcıların cinsiyet, yaş, medeni durum, aylık toplam gelir, sosyal güvence, hastaneye başvuru sıklığg, hizmet aldığı birim ve hastaneye gelme durumu arasında anlamlı bir farklılık tespit edilememiştir.

Anahtar Kelimeler: İmaj, Algılanan Kurumsal İmaj, Sağlık Kurumu.

\section{EVOLUATION OF PERCEIVED INSTUTIONAL IMAGE IN HEALTH INSTITUTIONS: AN EXAMPLE OF A PUBLIC HOSPITAL}

\section{Abstract}

\footnotetext{
${ }^{1} \mathrm{Bu}$ çalışma "Sağlık Kurumlarında Algılanan Kurumsal İmajın Değerlendirilmesi: Bir Kamu Hastanesi Örneği” başlıklı Yüksek Lisans Tezinden Türetilmiştir.

${ }^{2}$ Doç. Dr., Düzce Üniversitesi, Siyaset Bilimi ve Kamu Yönetimi Bölümü, suleyman.agras@ duzce.edu.tr

${ }^{3}$ Düzce Üniversitesi, Toplam Kalite Yönetimi Bölümü Y. Lisans Mezunu, seda_kaskir@ outlook.com
} 
Efforts in establishing an image in terms of corporate sustainability have become more of a necessity than preference. Conducting these corporate image making efforts in a conscious and systematic manner is extremely important for corporations that want to establish a positive image within the society. This study aims to determine the image perception of patients and relatives of patients that received healthcare services in the An Example of Public Hospital. The Corporate Image Questionnaire Form prepared by scanning literature reached 384 patients that received healthcare services using the face to face survey method. SPSS and AMOS programs were used to analyze the data collected between February-July 2020. Descriptive statistics, factor analysis, analysis of variance and the structural equality model were implemented for the data acquired. In accordance with the analysis and evaluations conducted, it was determined that the perception of a corporate image in health centers can be approached from 4 dimensions including communication, physical, quality and social responsibility. As a result of this research, it was determined that among the corporate image factors, participants mainly perceived the dimensions of quality and communication were more important, and the perception of physical and social responsibility was significantly lower. There was no significant difference established between the gender, age, marital status, total monthly income, social security; frequency of hospital visits, departments/clinics where the patients received services or reasons for hospital visits of the participants.

Key Words: Image, Perceived Instutional Image, Health Institution.

\section{GíRIŞ}

Sağlık, bir sanayi veya imalat sektöründeki gibi madde üzerinde işlem yapılan bir üretimden ziyade insan emeğine dayalı bir sektördür. Toplum tarafından sosyal bir hak olarak görülen ve hayati öneme sahip sağlık hizmetinden toplumun tamamının kaliteli ve güvenilir bir şekilde yararlanması, ülkelerin gelişmişlik düzeyinin göstergeleri arasında yer almaktadır. Sağlık kurumlarının, sundukları hizmetlerin kalitesini değişen toplumsal ihtiyaçlara, istek ve beklentilere cevap verebilecek şekilde yükseltmesi, hizmet alanların memnuniyet seviyesini yükselteceği gibi kurumsal imaj ve itibar açısından da oldukça önemlidir.

Günümüzde yaşanan hızlı değişim ve bu değişime bağlı olarak kişilerde meydana gelen algısal bakış açıları her alanda olduğu gibi sağlık sektöründe de kendisini göstermektedir. Bununla birlikte Türkiye'de özel sektörde sağlık hizmeti sunan kurumların artması, ihtisas hastaneleri yatırımları ve önde gelen sağlık grupları tarafından branş hastanelerinin açılması gibi gelişmeler bu alanda yaşanan rekabeti artırmanın yanı sıra hizmet kalitesi ve müşteri (hasta) memnuniyetini de sağlık kurumlarının gündeminin ilk sıralarına taşımıştır (DGH, 2019). Bu bakımdan sağlık kurumlarının, hedef kitleleri tarafından nasıl algılandığının tespit edilmesi ve etkili bir yönetim politikasıyla kurum üzerinde olumlu tutum oluşturmaya hassasiyet göstermeleri gerekmektedir.

Sağlık, insanların mutlu, huzurlu ve iyi bir yaşam sürmelerinde en önemli unsurların başında gelir. Sağlık hizmetlerinin aciliyeti, sürekliliği ve ötelenemez özelliği onu diğer 
hizmet sektörlerinden ayırmaktadır. Sağlığın toplumdaki bu önemi, sağlık hizmeti sunanları etkileyerek daha kaliteli hizmet sunmanın gerekliliğini ortaya çıkarmıştır. Diğer alanlarda olduğu gibi sağlık kurumlarının da kilit başarı faktörleri arasında ilişki içerisinde olduğu kitlelerin beklentilerini anlamak, kendilerini onlara doğru şekilde anlatmak ve tanıtmaktır. Öte yandan sağlık hizmetleri alanında yaşanan rekabet, sağlık kurumlarını güçlü ve pozitif bir kurumsal imaja sahip olmaya yönlendirmektedir.

Sağlık kurumlarının toplumun tamamını kapsayan geniş bir hedef kitlesi vardır. Sağlık kurumlarının olumlu imaj edinmesi zor olduğu kadar, edinilmiş imajlarını kaybetmeleri de çok kolaydır. Sağlık sektöründe özellikle hastane, doktor yada personeli hakkında ortaya çıkan iyi yada kötü değerlendirmeler, sağlık hizmetini alanların zihninde kurum hakkında bir algı oluşturarak hizmet alma tercihlerini etkilemektedir. Sağlık kurumlarında hastaların önceliklerinin tespit edilmesi, sağlık hizmeti alanların üzerinde olumlu imaj kurulmasına, hasta bağlılığının artmasına ve kurumun başarılı olmasına katkı sağlayacaktır. Bu çalışmanın amacı, Düzce'de faaliyet gösteren bir kamu hastanenin kurumsal imajının nasıl algılandığını, hastanenin kurumsal imajının düşük ve yüksek algılanan imaj boyutlarını, hastanenin kurumsal imaj düzeyi açısından farklı hedef kitleleri arasında anlamlı bir farklılık gösterip göstermediğini araştırmak ve hastanenin kurumsal imajının güçlendirilebilecek önerilerde bulunmaktır.

\section{KAVRAMSAL ÇERÇEVE}

\subsection{Kurumsal İmaj Kavramı}

İmaj kavramı, bir nesnenin nasıl bilindiği, tanımlandığı ve hatırlandığı ile ilgilidir (Van Riel ve Fomburn 2007: 40). Bir nesnenin insanlar tarafindan bilinen, tanınan, hatırlanan ve ilişki kurulan bir anlam kümesidir. İmaj, insanların zihinlerinde isteyerek veya istemeyerek bırakmış olduğu, fikirler, anlayışlar ve değerler şeklinde de ifade edilmiştir (Gümüş, 1995: 124). Bireyler, bir "bir şey" hakkında imaj kararı oluştururken içinde yaşadığ1 ortam, doğal ilişkiler ve sahip olduğu önyargılar gibi çok sayıda kanaldan gelen verileri zihin süzgecinden geçirir. Oluşan tüm izlenim ya da düşünceler bilinçli yada bilinçsiz şekilde gelişebilir. İnsan zihninde sonsuza kadar aynı şekilde kalmayan imaj, ağır ağır bir birikim sonucunda oluşmaktadır (Çorakçı, 2007:32).

Bouchet (2014: 4) imajı, şirketin piyasa (en azından en önemli izleyicileri) tarafından nasıl algılandığına yönelik atfedilmiş kimlik olarak tanımlamış ve imajın oluşmasının 
anahtar kavramlarının iyi niyet, itibar ve söylentiler olduğunu ifade etmiştir. Modern toplum anlayışının ortaya çıktığı 19. yüzyıl sonlarından itibaren oluşmaya başlayan imaj, 20. yüzyıl sonlarından itibaren ekonomik değere dönüşmeye başlamıştır. Ülkelerin, işletmelerin, kişilerin olumlu ve farklı bir imaj oluşturma çabaları, alanında uzman işletmelerin ve imajı yüksek kişilerin ortaya çıkmasına katkı sağlamıştır (Ün, 2016: 14). Kurumsal imaj algısı, kurumsal başarı ve büyümenin temel ölçülerinden biri olarak kabul edilmektedir (Bathmanathan ve Hironaka, 2016). Kurumsal imaj, bir kurumun faaliyetlerinin ve ürünlerinin, misyon, vizyon ve temel değerlerinin paydaşlar tarafından nasıl algılandığını açıklayan, maddi olmayan, organizasyonel sinyaller ve iletişim fonksiyonu sonucu oluşan değerli bir varlıktır (Kolade vd., 2014:39; Bhatti ve Awan, 2017:27). Aynı zamanda örgütlerin sosyal performansının bir göstergesi olan kurumsal imaj paydaşların organizasyonun eylemlerine yönelik algılarından oluşmaktadır (Riordan vd. 1997:401). Kurumsal imaj algısında en çok ön plana çıkarılan paydaş gruplarının müşteriler ve çalışanlar olduğu belirtilmiştir. Bu noktada kurumsal imaj, müşterilerin zihninde olan, kurum hakkındaki genel izlenim (Hsieh vd., 2004:252) olarak ifade edilmekle beraber; kurumun kamuoyunda canlandırdığı kanaat (Gürgen, 1990:44), kurumun hedef kitleleri tarafından algilanan resmi (Ak, 1998:20), kurumun kendisini çevresine gösterme yöntemi (Bromley, 2000: 241), kurumu meydana getiren tüm görsel, sözel ve davranışsal ögelerin bütünü (Howard,1998:4) kurumların çeşitli niteliklerinin karşıt ve benzerleri ile kıyaslanmasının sonucunda oluşan bir değer (Akıncı Vural ve Bat, 2013: 125) şeklinde tanımlanmıştır.

Tüm kurumların "kendine özgü” bir imajı olmakla birlikte pozitif imaj, kuruluşun "iyi işler” yapıp yapmadıklarıyla ilişkilidir. Kurumsal imajın "benzersiz" olabilmesi ise paydaşlarının algılarına bağlıdır. Pozitif kurumsal imaj, paydaşların belirli kurumsal eylemlere, ürünlere ya da mağazalara olan tepkilerini etkilemektedir (Upamannyu vd. 2015:21). Literatürde kurumsal imaj ile ilgili çok sayıda sınıflandırma bulunmaktadır. Tablo 1'de kurumsal imajla ilişkili sınıflamalara yer verilmiştir. 
Tablo-1: Kurumsal İmaj Sınıflaması

\begin{tabular}{ll}
\hline İmaj Sınıflaması & Tanım \\
\hline İstenilen İmaj & Kurumun gelecekte oluşturmak istediği imajdır (Bayramoğlu, 2007:12). \\
\hline Ürün İmajı & $\begin{array}{l}\text { Ürünlerin sembolik özellikleri (paketleme, reklam ve fiyat gibi) ile ilgili sahip olunan } \\
\text { bilgi, düşünce ve yargılardır (Han, 2006:20 ve Bilgin 2010: 138). }\end{array}$ \\
\hline Marka İmajı & Bir ürün benzersiz algılanışı ile ilişkilidir (Sallam, 2016:99). \\
\hline Ayna İmajı & $\begin{array}{l}\text { Kurum yöneticileri ve çalışanlarının kişiler üzerinde oluşturduğu düşünülen } \\
\text { imajdır(Kalaycı, 2004: 26). }\end{array}$ \\
\hline Yabancı İmaj & $\begin{array}{l}\text { Kurumun sunduğu ürün ve hizmetle doğrudan ilişkisi olmayan, kişilerin zihninde } \\
\text { kurum hakkında oluşturdukları görüş ve düşünceleridir (Çetin, 2016: 11). }\end{array}$ \\
\hline Taşınan/ & $\begin{array}{l}\text { Bir kurumun ya da onun tarafından üretilmiş bir ürünün sahip olduğu imajın başka bir } \\
\text { kurumda ve/ veya üründe kullanılması durumudur (Bolat, 2006, s. 11). }\end{array}$ \\
\hline Sransfer İmaj & $\begin{array}{l}\text { Kurumun bugünkü görüntüsü olarak, kuruma ilişkin deneyimlere ya da bilgilere göre } \\
\text { kurumun değerlendirilmesi sonucu oluşan imajdır (Akbulut, 2015). }\end{array}$ \\
\hline Negatif (Olumsuz) İmaj & $\begin{array}{l}\text { Kişi ya da kuruluş tarafından, toplumda onaylanmayan bir davranışın yaşanması, } \\
\text { sonucu zihinlerde oluşan olumsuz algılardır (Polat ve Arslan, 2015:19). }\end{array}$ \\
\hline Pozitif (Olumlu) İmaj & İyi deneyimler sonucu zihinlerdeki oluşan pozitif düşüncelerdir (Bolat, 2006: 12). \\
\hline Şemsiye İmaj & Kurum tüm faaliyet alanlarını içine alan en tepedeki imajdır (Okay, 2008:243). \\
\hline Mağaza İmajı & Mağazaya ilişkin izlenimler sonucu oluşan algılardır(Yücel ve Yücel, 2012: 100). \\
\hline
\end{tabular}

\subsection{Kurumsal İmajın Yönetimi}

Kurumsal imaj, kurumun hedef kitlesine verdiği görüntüsü, iletişimi ve tutumunu ifade ettiğinden oluşturulması zor ve uzun bir süreç gerektirmekte ancak göz ardı edildiğinde kuruma zarar verici olabilen bir niteliktedir (Gürbüz, 2017: 28). Bir kurumun kurumsal imajı paydaşların davranışını etkilediğinden, imajını birçok nedenden dolayı geliştirmek ve yönetmek için çaba göstermeleri gerekmektedir. Kurumsal imaj1 yönetmenin gereklilikleri şu şekilde sıralanmıştır (Adenike, 2015: 2):

- Kurumsal rekabet avantajının artırılmasıyla daha yüksek kârlılığa ulaşmak,

- $\quad$ İşyeri ve ortamılyla toplum arasında olumlu ilişkileri teşvik etmek,

- Yatırımcıları ve finansal kurumları etkilemek,

- Organizasyon için kurumsal kimlik oluşturmak,

- Çalışanlar için iyi bir kimlik oluşturmak ve böylece memnuniyeti sağlamak,

- Satışları ve müşteri sadakatini teşvik etmek,

- Hükümet, kanaat önderleri ve çeşitli çıkar gruplarıyla iyi ilişkiler geliştirmek. 
Kurumsal imaj, yönetilmesi gereken değerli bir varlık olduğundan pozitif bir imaj, artan müşteri memnuniyeti ile birlikte kurumsal performansı artırabilmekte, yatırımcıları ve çalışanları pozitif yönde etkileyebilmektedir. Rekabetin olumsuz etkilerini azaltarak organizasyonların daha yüksek kazanç seviyelerine ulaşmasını sağlamakta, marka değeri oluşturarak tüm paydaşlar için güçlü bir navigasyon aracı olarak kullanılabilmektedir. Bu bakımdan kurumlar için en önemli meydan okumalarından birisi rekabetçi ortamda güçlü ve olumlu bir kurumsal imajın oluşturulması ve yönetilmesidir (Amini vd. 2012: 195). Kurumsal imaj yönetimini etkileyen faktörler arasında, etkin liderlik, doğru politika ve stratejiler, varlık yönetimi, süreç yönetimi, müşteri ve çalışan memnuniyeti, sosyal sorumluluk ve iş sonuçları gibi unsurlar bulunmaktadır. Bu faktörlerle birlikte kurumsal imajı yönetmede üzerinde durulması gereken konular; kurum genel özellikleri, hedef kitledeki itibarı, kurumsal kültürü ve kimliğidir. $\mathrm{Bu}$ süreçte sosyal sorumluluk çalışmaları, güvenilirlik algısı, müşteri odaklılık ve kurumun somut imaj göstergelerine (logolar, renkler, sloganlar gibi) önem verilmelidir (Karyose, 2017: 338).

Kurumsal imajın, soyut bir kavram olması nedeniyle kurumların istenilen imaja ulaşabilmeleri için imajı etkileyen faktörlerin kuruma etkisinin tespit edilmesi önemlidir (Çerik ve Erkmen, 2006). İlgili literatürde çok boyutlu ve dinamik yapısı nedeniyle kurumsal imaj boyutlarının belirlenmesi noktasında farklılıklar bulunmaktadır. Tran ve arkadaşları (2015) kurumsal imaj oluşturma sürecinin görsel anlatım, olumlu duygular, çevre, kurum içi görünüm, çalışanların görünümü, tutum ve davranış ve dış iletişim olmak üzere 7 boyuttan etkilendiğini ortaya koymuştur. Nguyen ve Leblanc (2001) göre kurumsal imajın boyutları, kurumun adı, gelenekleri, vizyonu ve ürün/hizmet çeşitliliği de dâhil olmak üzere, müşterilerin deneyimleri, duyguları, fikir ve bilgisinin etkileşiminin toplamıdır. Keller (1998: 143) ise kurumun kendisi, sosyal çevresi, çalışanları, sosyal sorumluluk (yardımlar), satış gücü, ürünleri, fiyatı, satış sonrası hizmetleri, dağıtım kanalları ve iletişimi olmak üzere toplam 10 boyutun kurumsal imajının belirleyicileri olduğunu savunmuştur.

Kurumsal imajı yönetmek ve kitlelerle sürdürülebilir ilişki geliştirmek tek seferlik eylemlerden çok sürekli ve sinerjisi olan bir çabayı zorunlu kılmaktadır (Okoisama vd. 2017:18). Gray ve Balmer (1998), kurumlar için kritik ve değerli bir varlık olan bu kurumsal imajın oluşturulması ve korunması sürecini yönetmek için operasyonel bir model sunmuşlardır. 
Şekil-1: Kurumsal İmajı Yönetmek İçin Operasyonel Model

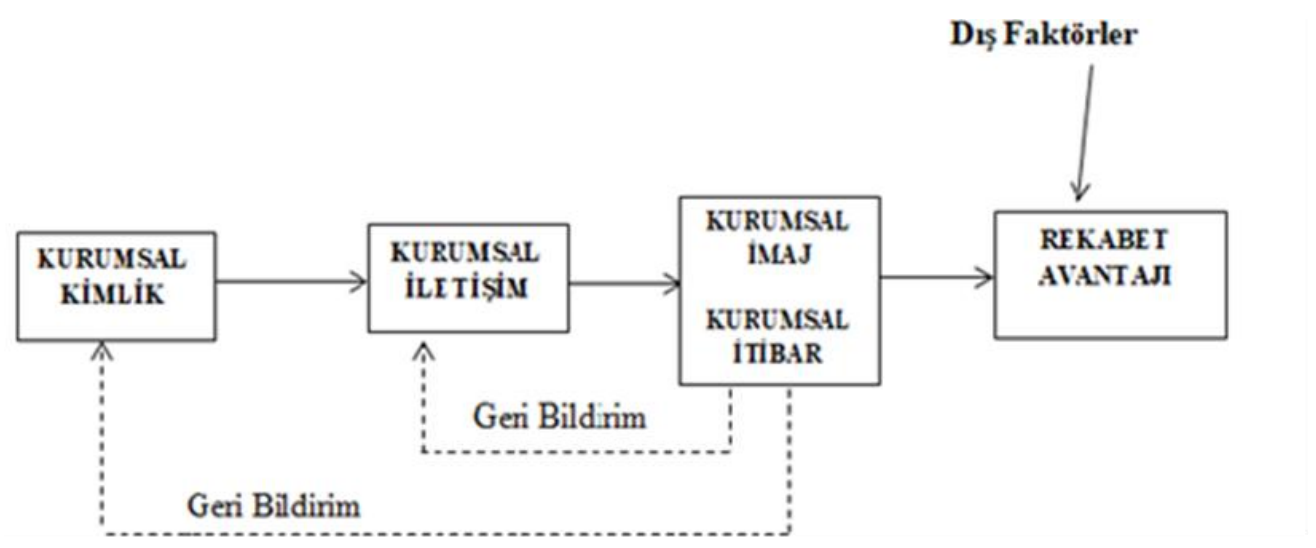

Kaynak: Gray ve Balmer, 1998

Model, kurumsal itibarı ve imajı anlamak için yöneticilerin firmalarının kurumsal kimliğini ve kurumsal iletişimi arasındaki karşılıklı ilişkileri anlamaları gerektiğini göstermektedir.

\subsection{Sağlık Kurumlarında Kurumsal İmaj Yönetimi}

Sağlık hizmetleri, kişilerin ve toplumun ihtiyaçlarını karşılamak ve sağlık bakımlarını koruyucu ve tedavi edici etkinliklerle sağlamak için ülke genelinde oluşturulmuş kalıcı sistem olarak tanımlanmaktadır (Yüksel, 2005: 4). Türkiye'de sağlık hizmetleri; sağlığın korunması, hastalıkların tedavi edilmesi ve rehabilitasyonu için yapılan çalışmalar doğrultusunda "koruyucu", "tedavi edici" "rehabilitasyon hizmetleri" olarak üç bölüme ayrılmaktadır (Akdur, 1999: 5). Türkiye'de sosyal güvenlik reformu ve özel girişimlerin artması sonucu olarak özel hastane ve sağlık merkezi sayısının artması ve hasta beklentilerinin çeşitlenmesi sağlık hizmeti sunan işletmeleri daha kaliteli ve etkin sağlık hizmeti sunmaya yöneltmiştir. Sadece önleyici, tedavi ve rehabilite edici hizmetler değil, insanların yaşam süresini ve kalitesini arttırıcı faaliyetler de sağlı hizmetlerinin ilgi alanı içerisine girmiştir (Aydoğan 2015: 19).

Sağlık kurumlarında imaj, hastalar tarafından hizmetlerin, eylemlerin, faaliyetlerin etkileşimine dayanan hastane hakkında algılanan bir izlenimdir. Hastalar, hastanelerin sahip oldukları kurumsal imajı hastaneye geldiklerinde, tedavi deneyimleri ve taburcu 
edilene kadarki süreçte görmektedirler. Sağlığını riske atmak istemeyecek olan hasta, hastane tercihinde bulunurken kafasında oluşturduğu izlenimlerden yola çıkarak güvenilir ve hizmet kalitesi daha yüksek olan hastaneyi tercih edecektir. Sağlık kurumlarında imaj, kurumun performansıyla bağlantılı olan değerli bir stratejik varlıktır. Bir hastanenin imajının iyi algılanması, rekabet avantajı sağlayacağı gibi hastaları çekmeye ve elde tutmaya da yardımcı olacaktır(Kolade vd., 2014).

Yüz yüze iletişimin en yoğun yaşandığı yer, sağlık hizmeti sunan kurumlardır. Dolayısıyla kaliteli hizmet tüm sağlık çalışanlarının sorumluluğu ile gerçekleşebilir. Çünkü verilen hizmetlerin bir alanında oluşabilecek aksaklıklar hastanenin tüm imajına etki edecektir. En üst yöneticisinden en alt kademedeki personelin ekip halinde görevini tam anlamıyla yapması, hastanenin imajını korumasını sağlayacaktır (Yanık, 2000: 64). Hastane yöneticilerinin hastane ile etkileşim içerisinde olan hasta, hasta yakını, çalışan, tedarikçi gibi toplumun çeşitli kesimlerinin kurum hakkındaki imaj algılarını ölçmesi kurumsal imajın yönetilmesi açısından oldukça önemlidir (Özata ve Sevinç, 2009: 13). Sağlık kurumlarında kurumsal imaj yönelik yapılan ölçümler, hastaların beklenti ve gereksinimlerinin daha iyi anlaşılmasını sağlayacağı gibi, hangi kriterleri göz önüne alarak imajlarını yönetmeleri gerektiği noktasında yol gösterici olacaktır (Bayın, 2013: 25).

Yapılan literatür incelemesinde araştırmaların ağırlıklı olarak sağlık hizmeti kullanıcılarının hastanelerle ilgili kurumsal imaj algılarını etkileyen faktörler üzerine yapıldığı görülmüştür. Çalışmaların hastanelerde kurumsal imaj ölçülürken iletişim, kalite ve fiziki yeterlilik faktörlerine yönelik olduğu ve ölçüm yapılırken bu boyutlar üzerinde durulması gerektiği vurgulanmıştır. Araştırmalarda hastane çalışanlarının özel ilgisi ve nezaketi, personele güven, erişilebilirlik, nitelikli hizmet çeşitliliği, hastane konforu (Yeşil, 2016), personelinin kıyafetinin işe göre standart olması, kalifiye olması, yaş ortalamasının genç personelden oluşması, kurumun merkeze göre konumlandırılması, kurum personelinin hizmetten yararlananlara karşı yaklaşımları, hizmet sunumunun güvenilir, hızlı, doğru olması ve işletmenin kamuoyunda güvenilirliği (Bektaş, 2015) gibi unsurların kurumsal imaj algılarında etkili olduğu tespit edilmiştir.

Olumlu bir hastane imajının nasıl olması gerektiğini inceleyen Turgut (2003), bireylerin hastane seçme nedenlerinin başında başarılı doktor olması, hastanelerin bilimsel ve 
teknolojik gelişmeleri iyi takip etmesi, hastanenin kullandığı cihaz ve teknolojilerin modern olması ve hastanenin temiz olmasının etkili olduğunu tespit etmiştir. Çalışmada ayrıca tedavi sürelerinin uzunluğu, tedavi işlemlerinin karmaşık olması, doktor ve personelden yeterli bilgi almaması, personel davranışlarının iyi olmamasının da hastaneyi tercih edenlerin rahatsız olduğu unsurlar olduğu saptanmıştır. Aksoy ve Bayramoğlu (2008) tarafından yapılan çalışmada sağlık tüketicilerinin kurumsal imajı tanımlarken sırasıyla personel kıyafeti, kurumsal iletişim, personel davranışı ve tutarlılık, tüketici kolaylık maliyetleri, hizmet çeşitliliği ve bölümler arası erişim faktörlerini daha çok önemsedikleri bulgusuna erişilmiştir.

Sağlık kurumlarında kurumsal imaj konusunda yapılan araştırmalarda kurumsal imaj ve hizmet kalitesi, hasta memnuniyeti, hasta bağlılığı ve hasta sadakati arasındaki ilişkiler incelenmiştir. Bu çalışmalarda hasta memnuniyeti ve kurumsal imajı etkileyen en önemli unsurun "güven” olduğu (Bankaoğlu, 2013); hizmet kalitesi algısının kurumsal imajı güçlü bir şekilde etkilediği, kalite algısındaki her bir artışın kurumsal imaj algısını pozitif etkilediği (Öncü, 2018); olumlu kurumsal imaj algısının hastaların hastaneye bağl1lı̆̆g/sadakati arttırdığg ve personel davranışlarını etkilediği (Deniz ve Yüksel, 2018; Wu, 2011; Laohasirichaikul vd. 2011 ve İzci ve Saydan (2013), doktor performans1 ve hizmet kalitesine bağlı olarak hastaların zihninde oluşan kurumsal imajın sağlık kuruluşunun tercih edilirliğini ve rekabet gücünü arttırdığı (Akbolat vd.,2017; Korkmaz ve Çuhadar, 2017 ve Kim vd., 2017) tespit edilmiştir. Emül (2008) kurumsal imaj ve hasta memnuniyeti arasındaki güçlü ilişkiden yola çıkarak, hasta memnuniyetini arttırmak isteyen sağlık kuruluşlarının kurumsal imaj stratejilerine önem vermeleri gerektiğini ifade etmiştir.

\section{ARAŞTIRMA YÖNTEMI}

\subsection{Araştırma Amacı ve Modeli}

Bu araştırmada Düzce'de faaliyet gösteren bir kamu hastanesinin hasta ve hasta yakınları tarafından "mevcut imajını" fiziksel faktörler, iletişim, kalite ve sosyal sorumluluk faktörleri açısından incelenmesi amaçlanmıştır. Ayrıca hastanenin kurumsal imajının olumlu ve olumsuz yönleri, farklı kitleler tarafından kurumsal imaj düzeyinin anlamlı bir farklılık gösterip göstermediğinin belirlenmesi hedeflenmiştir. 
$\mathrm{Bu}$ amaca ulaşmak için tarama modeli temelinde nicel bir araştırma yürütülmüştür. Saha taraması, inceleme yöntemi ve survey araştırması olarak farklı terimlerde ifade edilen tarama modeli ise, geçmişte var olan ya da mevcutta devam eden durumu olduğu haliyle tasvir etmeyi amaçlar (Karasar,1999).

\section{Şekil-2: Araştırma Modeli}

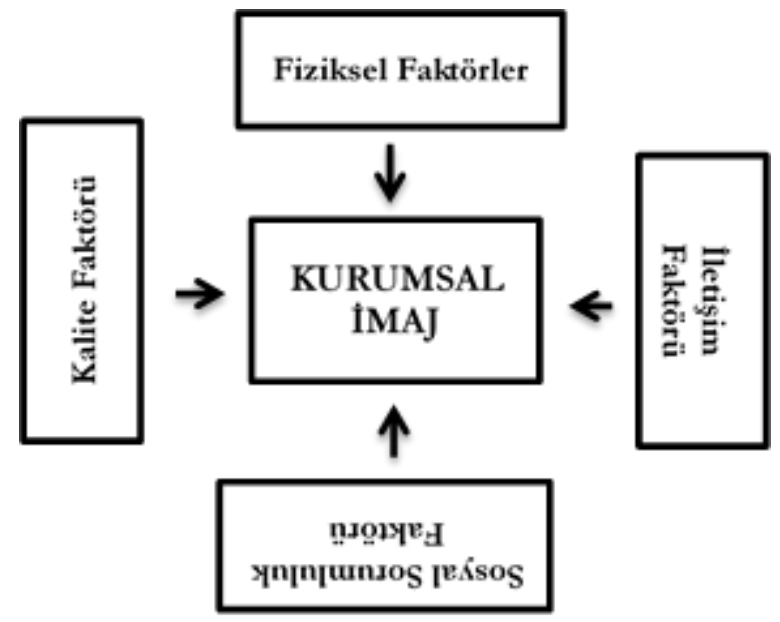

Araştırma modelinin temel varsayımı modelde yer alan 4 faktörün kurumsal imaj algısı üzerinde etkili olduğudur. Bu varsayımın temeli literatür incelemesinde yer alan bu alanda yapılmış araştırma sonuçlarıdır. Model, bu alanda farklı zaman ve mekânlarda yapılmış araştırmaların sonuçlarını birleştirme ve bir kamu hastanesi özelinde test etme olanağı sunmaktadır.

\subsection{Evren ve Örneklem}

Bu araştırmanın evrenini Düzce'deki bir kamu hastanesinden acil, klinik (yatan) ve poliklinik (ayaktan) hizmet alan hasta veya hasta yakınları oluşturmaktadır. Araştırmada örneklem büyüklüğünün hesaplanmasında bir yıllık hasta başvuru sayısı temel alınmıştır. Buna göre Hastanenin Ocak 2020 verilerine göre 39 bin 14 ayaktan hasta, 17 bin 196 acil hasta, 3 bin 204 yatan hasta olmak üzere toplam 59 bin 414 hasta sağlik hizmeti almak için başvuruda bulunmuştur. Sekaran'1n örnek büyüklüğünü gösterdiği tabloya göre; 0,95 güvenirlik ve 0,05 örneklem hata payı kriterlerine göre 50 bin ve üzeri evren için 381 örnek büyüklügü temsil etmektedir. Araştırma için eksik veya hatalı cevaplar düşünülerek katılımcılara 400 anket formu hasta ve hasta yakınlarına dağıtılmıştır. Geçersiz anket formları çıkarıldıktan sonra analiz için geçerli olan 384 adet anket, belirlenen örneklemin evreni temsil etme düzeyini karşıladığından analize dâhil edilmiştir. Örnekleme yöntemi 
olarak oransal olarak kota örneklemesi yöntemi tercih edilmiştir. Evrenin değişik kategorilere bölen kota örneklemesi yönteminde, her bir kategoride bulunan elemanın sayısı ile orantılı, onları temsil eden gruplarla örneklem oluşturulmaktadır (Özen ve Gül, 2007). Araştırmada örnek büyüklüğü, hasta ve hasta yakınlarının hizmet aldığı acil, ayaktan ve yatan hasta olarak bölüm bazında kotalara ayrıştırılmıştır. 400 anket formu, birimlere yapılan hasta başvuru oranları göz önüne alınarak 263'ü Poliklinik, 116'sı Acil Servis ve 21'i yataklı servisler olmak üzere üç kotaya bölünmüştür.

\subsection{Veri Toplama Aracı ve Süreci}

Verilerin elde edilmesinde iki bölümden oluşan bir anket kullanılmıştır. Anketin ilk bölümü literatürde yer alan ölçeklerden yola çıkarak hazırlanan kurumsal imaj ölçeği kullanılmıştır. Kurumsal imajı oluşturan 4 faktör (Fiziksel, İletişim, Kalite ve Sosyal Sorumluluk) ile ilgili 44 ifadeye yer verilmiştir.

Araştırmada kullanılan kurumsal imaj ölçeği için Bayın (2013) ve Yağmuroğlu (2018) 'nun araştırmalarında kullandığı veri toplama aracı temel alınmış olup, literatürdeki diğer kaynaklardan (Emül ve Naldöken, 2019; Yağmuroğlu, 2018; Koçyiğit vd., 2018; Bıçakç1, 2011; Cingöz ve Akdoğan, 2011; Aksoy ve Bayramoğlu, 2008; Turgut, 2003) faydalanılarak ölçek geliştirilmiştir. Geçerli ve güvenilir sonuçlar elde etmek açısından geliştirilen kurumsal imaj ölçeğine ön uygulama yapılmıştır. Anketteki soru sayısı göz önüne alınarak ön uygulamanın yapılacağı grup büyüklüğü belirlenmiştir. Anket, araştırmanın yapılacağı hastanede 50 poliklinik hastasına uygulanarak; anket formuna son düzenlemeler yapılmıştır. Anketteki 44 ifade 5'li likert ölçeği ile değerlendirilmiş, veriler katılımcıların katılma durumlarına göre "kesinlikle katılmıyorum", "katılmıyorum", “Orta Derecede Katıliyorum", "Katıliyorum" ve "Kesinlikle katılıyorum" şeklinde düzenlenmiştir. 44 soruya ek olarak 1 ifadede ankete katılanlardan hastanenin hizmet kalitesini puanlandırması, 1 soruda da birden fazla seçenek sunularak tercih nedenlerini belirtmeleri istenmiştir. Anketin ikinci bölümünde ise hastalara ilişkin demografik özellikleri belirleyici sorulara yer verilmiştir. Anket formu Şubat- Temmuz 2020 tarihlerinde 384 hasta ve hasta yakınıyla yüz yüze görüşülerek doldurulmuştur. Bunlardan geçerli olan 384 anket analize dâhil edilirken, 16 anket ise eksik veya hatalı cevaplardan dolayı geçersiz oldukları için analize dâhil edilmemiştir. Uygulama sırasında, acil sağlık hizmetlerinde katılımcıların sağlık sorunları nedeni ile ankete 
katılmak istememeleri belirlenen kotalara ulaşmada soruna yol açmıştır. Bu nedenle acil bölümünde yanıtlayıcı bulunamaması nedeniyle anket formları hasta yoğunluğunun en çok olduğu diğer bölümlerde uygulanmıştır.

\section{BULGULAR VE YORUM}

\subsection{Katılımcılarla İlgili Bilgiler}

Anketi yanıtlayan katılımcılarla ilgili tanımlayıcı istatistikler tablo 2'de yer almaktadır.

Tablo-2: Katılımcıların Demografik Özellikleri ve Belirli Değişkenlere Göre Dağılımı

\begin{tabular}{|c|c|c|c|}
\hline Değiş̧ken & Düzey & $n$ & $\%$ \\
\hline \multirow{2}{*}{ Cinsiyet } & Kadın & 186 & 48,4 \\
\hline & Erkek & 198 & 51,6 \\
\hline \multirow{5}{*}{ Yaş } & $18-24$ & 70 & 18,2 \\
\hline & $25-34$ & 114 & 29,7 \\
\hline & $35-44$ & 100 & 26,1 \\
\hline & $45-54$ & 57 & 14,8 \\
\hline & 55 ve üstü & 43 & 11,2 \\
\hline \multirow{2}{*}{ Medeni Durum } & Evli & 234 & 60,9 \\
\hline & Bekâr & 150 & 39,1 \\
\hline \multirow{6}{*}{ Öğrenim Durumu } & Okuryazar değil & 6 & 1,6 \\
\hline & İlköğretim & 84 & 21,9 \\
\hline & Lise & 113 & 29,4 \\
\hline & Ön Lisans & 44 & 11,5 \\
\hline & Lisans & 122 & 31,8 \\
\hline & Lisans Üstü & 15 & 3,8 \\
\hline \multirow{5}{*}{ Gelir } & 2000 TL ve Alt1 & 94 & 24,5 \\
\hline & 2001-3000 TL & 127 & 33,1 \\
\hline & $3001-4000 \mathrm{TL}$ & 63 & 16,4 \\
\hline & $4001-5000 \mathrm{TL}$ & 40 & 10,4 \\
\hline & 5001 TL ve Üstü & 60 & 15,6 \\
\hline \multirow{7}{*}{ Hizmet Alınan Birim } & Poliklinik (Ayakta) & 234 & 60,9 \\
\hline & Klinik (Yatarak) & 33 & 8,6 \\
\hline & Her İkisi (Ayakta ve Yatarak) & 46 & 12,1 \\
\hline & Acil Servis & & \\
\hline & Poliklinik Acil & 47 & 12,2 \\
\hline & Hepsi & 10 & 2,6 \\
\hline & & 14 & 3,6 \\
\hline Toplam & & 384 & 100 \\
\hline
\end{tabular}

\subsection{Faktör Analizleri}

\subsubsection{Açıklayıcı Faktör Analizi (AFA)}

Katılımcıların kurumsal imaj algılarını oluşturan veriler üzerinden açıklayıcı faktör analizi yapılmıştır. Kurumsal imajın alt değişkenlerini sağlık sektörü kapsamında 
tanımlamak amacıyla gerçekleştirilen açıklayıcı faktör analizi sonuçları aşağıdaki tablo 3'de verilmiştir.

Tablo-3: Kurumsal İmaj Açıklayıcı Faktör Analizi Sonuçları

\begin{tabular}{|c|c|c|c|c|c|}
\hline Faktörler & Değişken & Ort. & $\begin{array}{l}\text { Faktör } \\
\text { Yükleri }\end{array}$ & $\begin{array}{c}\text { Açlklanan } \\
\text { Varyans }\end{array}$ & $\begin{array}{c}\ddot{O} z \\
\text { Değer }\end{array}$ \\
\hline \multirow{8}{*}{ Fiziksel Faktör } & Fiziksel 1 & 3,89 & ,758 & \multirow{8}{*}{45,840} & \multirow{8}{*}{16,044} \\
\hline & Fiziksel 2 & 3,38 & ,718 & & \\
\hline & Fiziksel 3 & 3,25 & ,564 & & \\
\hline & Fiziksel 5 & 3,23 & ,568 & & \\
\hline & Fiziksel 8 & 3,09 & 652 & & \\
\hline & Fiziksel 9 & 3.08 & ,679 & & \\
\hline & Fiziksel 10 & 3,46 & ,513 & & \\
\hline & Fiziksel 12 & 3,10 & ,547 & & \\
\hline \multirow{8}{*}{ İletişim Faktörü } & İletişim 16 & 3,66 & ,701 & \multirow{8}{*}{5,811} & \multirow{8}{*}{2,034} \\
\hline & İletişim 17 & 3,54 & 679 & & \\
\hline & İletişim 18 & 3,61 & 699 & & \\
\hline & İletişim 19 & 3,59 & 609 & & \\
\hline & İletişim 20 & 3,66 & ,755 & & \\
\hline & İletişim 21 & 3,39 & 651 & & \\
\hline & İletişim 22 & 3,40 &, 552 & & \\
\hline & İletişim 23 & 3,34 &, 533 & & \\
\hline \multirow{11}{*}{ Kalite Faktörü } & Kalite 24 & 3,58 & ,638 & \multirow{11}{*}{4,112} & \multirow{11}{*}{1,439} \\
\hline & Kalite 25 & 3,36 & 651 & & \\
\hline & Kalite 26 & 3,62 & ,720 & & \\
\hline & Kalite 28 & 3,68 & 679 & & \\
\hline & Kalite 29 & 3,68 & ,696 & & \\
\hline & Kalite 30 & 3,56 & ,741 & & \\
\hline & Kalite 31 & 3,61 & ,676 & & \\
\hline & Kalite 32 & 3,62 & 629 & & \\
\hline & Kalite 33 & 3,70 & 626 & & \\
\hline & Kalite 34 & 3,19 & ,557 & & \\
\hline & Kalite 36 & 3,41 & ,536 & & \\
\hline \multirow{8}{*}{$\begin{array}{l}\text { Sosyal Sorumluluk } \\
\text { Faktörü }\end{array}$} & Sosyal S.37 & 3,42 & ,706 & \multirow{8}{*}{3,352} & \multirow{8}{*}{1,173} \\
\hline & Sosyal S.38 & 3,38 & 699 & & \\
\hline & Sosyal S.39 & 3,35 & ,765 & & \\
\hline & Sosyal S.40 & 3,22 &, 723 & & \\
\hline & Sosyal S.41 & 3,29 & 691 & & \\
\hline & Sosyal S.42 & 3,48 & ,757 & & \\
\hline & Sosyal S.43 & 3,35 & ,757 & & \\
\hline & Sosyal S.44 & 3,41 & ,760 & & \\
\hline Değerlendirme & \multicolumn{5}{|c|}{ Kaiser-Meyer Olkin Measure of Sampling Adequacy: 0,959 } \\
\hline \multirow[t]{5}{*}{ Kriterleri } & \multicolumn{5}{|c|}{ Approx. Chi-Square: : 9061,061 } \\
\hline & \multicolumn{5}{|c|}{ Barlett's Test of Sphericity: 0,000 } \\
\hline & \multicolumn{5}{|c|}{ Extraction Method: Principal Components } \\
\hline & \multicolumn{5}{|c|}{ Rotation Method: Varimax } \\
\hline & \multicolumn{5}{|c|}{ Açıllanan Varyans Toplamı: 59,115 } \\
\hline
\end{tabular}

Kurumsal İmaj ölçeği ile yapılan anket çalışması sonucunda Faktör I, Faktör II, Faktör III ve Faktör IV alt boyutları olmak üzere toplam 35 maddelik bir ölçek geliştirilmiştir. $\mathrm{Bu}$ ölçeğin yapısal geçerliliğini tespit edebilmek için temel bileşenler analizi ve eksen 
döndürme tekniği uygulanarak AFA yapılmıştır. Bunun sonucunda (KMO) örneklem yeterlilik değeri 0,959 olduğu, Bartlett's Test (Ki-Kare: 9061,061, df:595, p:,000) olduğu görülmektedir ve örneklem büyüklüğünün faktör analizi açısından yeterli düzeyde olduğu saptanmıştır. Faktör analizi yapılırken Kurumsal İmaj ölçeğindeki bazı ifadelerin yüklerinin düşük olması $(<0,50)$ nedeniyle kapsam dışı bırakılarak ölçek yenilenmiştir.

\subsubsection{Doğrulayıcı Faktör Analizi (DFA)}

Doğrulayıcı Faktör Analizi (DFA), Açıklayıcı Faktör Analizine (AFA) ek olarak yapılmakla birlikte, daha önceden belirlenen bir faktöriyel yapının doğruluğu test etmek için kullanılmaktadır (Erdoğan vd., 2007:10). Bu bölümde, keşfedici faktör analizi ile belirlenen faktör yapıları doğrulayıcı faktör analizi ile test edilmiştir. AFA yapılmış olan kurumsal imaj ölçeğine, DFA yapılarak verinin varsayılan modele uyum derecesi test edilmiştir.

Şekil-3: Kurumsal İmaj Araştırma Modeli (Ölçüm Modeli) ve Uyum İyiliği Sonuçları

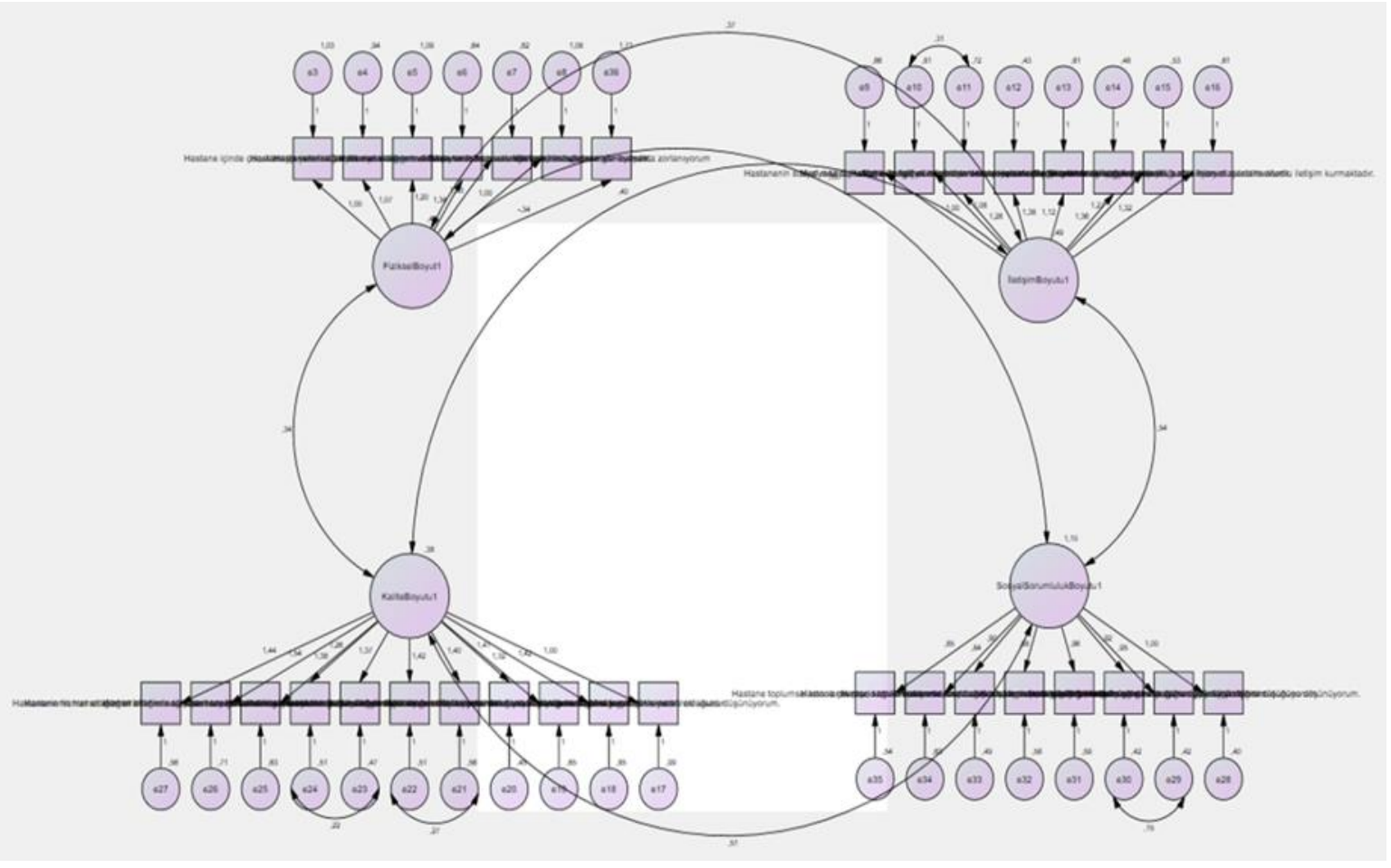

[(X2/df: 2.385; GFI: 0.84; NFI: ,917; CFI: 0.91; RMSEA: 0.060; Model AIC =1389,003; Independence AIC =9248,152 Model CAIC =1775,153; Independence CAIC =9416,474; ECVI: 3,627; ECVI Independence Model =24,147)

Tablo 5 ölçüm modelindeki değişkenlerin faktör yüklerini, standart hatalarını, tdeğerlerini, açıklanan varyanslarını ve güvenirlilik düzeylerini göstermektedir. 
Tablo-4: İyileştirilmiş Ölçüm Modeline İlişkin İkinci Düzey DFA Sonuçları

\begin{tabular}{|c|c|c|c|c|c|}
\hline Örtük Değişskenler & $\begin{array}{l}\text { Gözlenen } \\
\text { Değişkenler }\end{array}$ & $\begin{array}{c}\text { Standartlaştırılmış } \\
\text { Regresyon Katsayıları }\end{array}$ & $\begin{array}{c}\text { Standart } \\
\text { Hata }\end{array}$ & T Değeri & $p$ \\
\hline \multirow{6}{*}{ Fiziksel Faktörler } & M9 &, 565 & & & \\
\hline & M8 & 610 &, 118 & 9,135 & $* * *$ \\
\hline & M5 & 625 &, 130 & 9,287 & $* * *$ \\
\hline & M3 &, 720 &, 128 & 10,454 & $* * *$ \\
\hline & M2 & ,622 &, 112 & 9,251 & $* * *$ \\
\hline & M1 &, 555 &, 117 & 8,547 & $* * *$ \\
\hline \multirow{8}{*}{ İletişim Faktörü } & M23 & & & 10,516 & \\
\hline & M22 & ,641 & , 102 & 11,500 & $* * *$ \\
\hline & M21 &, 723 &, 111 & 12,564 & $* * *$ \\
\hline & M20 &, 824 &, 110 & 11,341 & $* * *$ \\
\hline & M19 & ,709 & 099 & 12,404 & $* * *$ \\
\hline & M18 & ,808 &, 110 & 12,036 & $* * *$ \\
\hline & M17 & ,772 & , 106 & 11,930 & $* * *$ \\
\hline & M16 & ,762 &, 111 & 10,516 & $* * *$ \\
\hline \multirow{11}{*}{ Kalite Faktörü } & M36 &, 524 & & 9,784 & \\
\hline & M34 & ,686 &, 145 & 9,960 & $* * *$ \\
\hline & M33 & ,709 & ,132 & 10,534 & $* * *$ \\
\hline & M32 & ,789 &, 134 & 10,285 & $* * *$ \\
\hline & M31 &, 753 &, 136 & 10,421 & $* * *$ \\
\hline & M30 & ,773 &, 137 & 10,450 & $* * *$ \\
\hline & M29 & ,777 &, 132 & 10,143 & $* * *$ \\
\hline & M28 & ,734 &, 124 & 10,124 & $* * *$ \\
\hline & M26 &, 730 &, 136 & 10,237 & $* * *$ \\
\hline & M25 &, 746 &, 150 & 10,347 & $* * *$ \\
\hline & M24 &, 762 & ,139 & 9,784 & $* * *$ \\
\hline \multirow{8}{*}{ Sosyal Sorumluluk } & M44 & 857 & & & \\
\hline & M43 & ,839 &, 045 & 21,092 & $* * *$ \\
\hline & M42 & ,829 &, 044 & 20,645 & $* * *$ \\
\hline & M41 & ,794 &, 050 & 19,274 & $* * *$ \\
\hline & M40 & ,773 & ,048 & 18,449 & $* * *$ \\
\hline & M39 & ,803 &, 046 & 19,634 & $* * *$ \\
\hline & M38 &, 745 &, 048 & 17,419 & $* * *$ \\
\hline & M37 & ,772 &, 046 & 18,409 & $* * *$ \\
\hline
\end{tabular}

$* * * \mathrm{p}<0.01$

Araştırma modelinde, kurumsal imaj, fiziksel faktör (FF), iletişim faktörü (IF), kalite faktörü (KF), sosyal sorumluluk faktörü (SSF) değișkenleri ile temsil edilmektedir. Bu nedenle kurumsal imajın açıklayan dört boyutun kurumsal imajı anlamlı bir biçimde açıklayıp açıklayamadığını değerlendirmek için ikinci derece faktör analizi gerçekleştirilmiştir. Program çıktısı olarak verilen modifikasyon indeksleri dikkate alınmış ve en yüksek değere sahip hata çiftleri eşleştirilerek uyum iyiliği indekslerinin 
düzeltilmesi amaçlanmıştır. Bu amaçla M10-M11, M22-M21, M24-G23, M30-M29 değişkenlerine ait hatalar çiftleştirilmiş ve Tablo 5' de yer alan uyum iyiliği değerleri elde edilmiştir.

DFA sonuçları incelendiğinde gözlenen değişkenlere ait standartlaştırılmış regresyon katsayıları, $t$ değerleri $(t>1.96)$, $p$ değerleri $(p<0.01)$ ve model uyum iyiliği indeksleri modelin genel olarak kabul edilebilir uyum düzeyinde olduğunu göstermektedir. Tablo 15 'te literatürde genel kabul gören iyilik uyum indeksi değerleri analiz sonrası elde edilen değerler gösterilmiştir.

Tablo-5: Ölçüm Modeli Uyum İyiliği İndeksleri

\begin{tabular}{lccc}
\hline Genel Model Uyumu & İyi Uyum & $\begin{array}{c}\text { Kabul Edilebilir } \\
\text { Uyum }\end{array}$ & $\begin{array}{c}\text { Elde Edilen Uyum } \\
\text { Değerleri }\end{array}$ \\
\hline $\boldsymbol{x}^{2} / \boldsymbol{s} \boldsymbol{d}$ & $\leq 3$ & $\leq 5$ & $\mathbf{2 , 3 8 5}$ \\
$\boldsymbol{N F I}$ & $\geq 0.95$ & $\geq 0.90$ & $\mathbf{8 6 6}$ \\
$\boldsymbol{C F I}$ & $\geq 0.97$ & $\geq 0.95$ & $\mathbf{9 1 7}$ \\
$\boldsymbol{I F I}$ & $\geq 0.95$ & $0.94-0.90$ & $\mathbf{9 1 7}$ \\
$\boldsymbol{A G F I}$ & $>0.95$ & $\geq 0.85$ & $\mathbf{8 1 6}$ \\
$\boldsymbol{G F I}$ & $\geq 0.90$ & $0.89-0.85$ & $\mathbf{8 4 0}$ \\
$\boldsymbol{R M R}$ & $<0.05$ & $<0.08$ & $\mathbf{0 6 6}$ \\
\hline
\end{tabular}

\subsubsection{Kurumsal İmaj Faktörleri İle İlgili Tanımlayıcı İstatistikler}

Açıklayıcı faktör analizinden sonra, elde edilen değişkenlerle ilgili tanımlayıcı istatistikler incelenmiştir. Her bir değişkene ait ortalamalar, standart sapmalar, güvenilirlik katsayıları, soru sayıları ve kullanılan ölçek düzeyleri ile ilgili bilgiler aşağıdaki tabloda verilmiştir.

Tablo 6. Faktörler İle İlgili Tanımlayıcı İstatistikler

\begin{tabular}{llccccc}
\hline Yapılar & Faktörler & Ort. & $\begin{array}{c}\text { Std. } \\
\text { Sapma }\end{array}$ & $\begin{array}{c}\text { Soru } \\
\text { Sayısı }\end{array}$ & $\begin{array}{c}\text { Güvenilirlik } \\
\text { Katsayıst }\end{array}$ & $\begin{array}{c}\text { Ölçek } \\
\text { Düzeyi }\end{array}$ \\
\hline & Fiziksel & 3,31 & 0,72 & 8 &, 718 & 5 \\
& İletişim & 3,52 & 0,90 & 8 &, 903 & 5 \\
& Kalite & 3,55 & 0,87 & 11 &, 924 & 5 \\
& Sosyal Sor. & 3,36 & 0,99 & 8 &, 935 & 5 \\
\hline Kurumsal & $\mathbf{3 , 4 4}$ & $\mathbf{0 , 7 7}$ & $\mathbf{3 5}$ & $\mathbf{9 6 1}$ & $\mathbf{5}$ \\
& & & & & \\
\hline
\end{tabular}

Ölçeğin güvenirliğinin belirlenmesi amacıyla Cronbach's Alfa güvenirlik katsayıları hesaplanmıştır. Ölçeklerin Cronbach's Alpha değerleri 0,718 ile 0,961 arasındadır. Bu 
duruma göre ölçek oldukça güvenilirdir. Toplam güvenilirlik katsayısı ise; 0,961 olarak bulunmuştur.

Tablo-7: Katılımcıların İkamet Durumlarına Göre T-Testi Sonuçları

\begin{tabular}{llrcccc}
\hline Faktörler & $\begin{array}{c}\text { Ikamet } \\
\text { Durumu }\end{array}$ & $\boldsymbol{N}$ & Ort. & $\begin{array}{c}\text { Std. } \\
\text { Sapma }\end{array}$ & $\boldsymbol{t}$ & $\boldsymbol{p}$ \\
\hline \multirow{2}{*}{ Sosyal Sorumluluk } & Düzce & 291 & 3,3015 &, 99942 & \multirow{2}{*}{ (039* } \\
& Düzce D1ş1 & 93 & 3,5457 &, 96258 & $-2,069$ & $\mathbf{. 0 3}$ \\
\hline
\end{tabular}

*Gruplar arası farklılık 0,005 düzeyinde anlamlıdır.

İkamet ile ölçek arasındaki ilişkiye bakıldığında; katılımcıların fiziksel, iletişim ve kalite algıları ikametlerine göre anlamlı bir farklılık göstermemektedir. Fakat katılımcıların sosyal sorumluluk algıları ikametlerine göre anlamlı bir farklılık göstermektedir. Düzce dışında ikamet edenlerin sosyal sorumluluk algılarının Düzce içerisinde yaşayanlara göre daha olumlu olduğu görülmektedir.

Tablo-8: Kurumsal İmaj-Öğrenim Durumu ANOVA Sonuçları

\begin{tabular}{llcccccc}
\hline \multirow{2}{*}{ Faktörler } & $\begin{array}{c}\text { Varyansin } \\
\text { kaynağı }\end{array}$ & $\begin{array}{c}\text { Karaler } \\
\text { Toplamı }\end{array}$ & Sd & $\begin{array}{c}\text { Kareler } \\
\text { Ort. }\end{array}$ & $f$ & $\boldsymbol{p}$ & $\begin{array}{c}\text { Anlamlı } \\
\text { Fark }\end{array}$ \\
\hline \multirow{4}{*}{ Fiziksel } & Gruplararasi & 7,750 & 5 & 1,550 & 3,024 & $\mathbf{. 0 1 1 *}$ & Lise- \\
& Grupiçi & 193,744 & 378 &, 513 & & & Lisans
\end{tabular}

*Gruplar arası farklılık 0,05 düzeyinde anlamlıdır.

Katılımcıların kurumsal imaj boyutlarından iletişim, kalite ve sosyal sorumluluk boyut algıları ile öğrenim durumu arasında anlamlı bir farklılık görülmemektedir. Bununla birlikte öğrenim durumu ile fiziksel boyut katılımcıların öğrenim durumlarına göre anlamlı bir farklılık göstermektedir. Farklılık lise mezunu ve lisans mezunu olanlar arasındadır. Tanımlayıcı istatistiklerden lise mezunu olanların, lisans mezunu olanlara göre hastanenin fiziki şartlarını daha nitelikli bulduğu anlaşılmıştır.

Tablo-9: Kurumsal İmaj-Meslek ANOVA Sonuçları

\begin{tabular}{llcccccc}
\hline Faktörler & $\begin{array}{c}\text { Varyansın } \\
\text { kaynağı }\end{array}$ & $\begin{array}{c}\text { Karaler } \\
\text { Toplamı }\end{array}$ & Sd & $\begin{array}{c}\text { Kareler } \\
\text { Ort. }\end{array}$ & $\boldsymbol{f}$ & $\boldsymbol{p}$ & $\begin{array}{c}\text { Anlamlı } \\
\text { Fark }\end{array}$ \\
\hline & Gruplararası & 7,764 & 6 & 1,294 & 2,518 & $\mathbf{. 0 2 1 *}$ & $\begin{array}{c}\text { Emekli- } \\
\text { Kamu } \\
\text { Fiziksel }\end{array}$ \\
Grupiçi & 193,730 & 377 &, 514 & & & $\begin{array}{c}\text { görevlisi } \\
\text { İşi- } \\
\end{array}$ \\
Toplam & 201.494 & 383 & & & & $\begin{array}{c}\text { Ozel } \\
\text { sektör }\end{array}$ \\
\hline
\end{tabular}

*Gruplar arası farklılık 0,05 düzeyinde anlamlıdır. 
Katılımcıların kurumsal imaj boyutlarından iletişim, kalite ve sosyal sorumluluk boyut algıları ile meslek arasında anlamlı bir farklılık görülmemektedir. Bununla birlikte meslek ile fiziksel boyut, katılımcıların mesleklerine göre anlamlı bir farklılık göstermektedir. Emekliler, kamu görevlisi, işçi ve özel sektörde çalışanlara göre hastanenin fiziki şartlarının daha iyi olduğunu düşünmektedirler. Emeklilerin hastanenin fiziki şartlarını diğerlerine göre daha olumlu algıladıkları görülmektedir.

\subsubsection{Hastanenin Hizmet Kalitesinin Genel Değerlendirmesi}

Hastanenin hizmet kalitesinin değerlendirilmesiyle ilgili sonuçlar aşağıda verilmiştir.

Tablo 10. Hastanenin Genel Hizmet Kalitesinin Değerlendirilmesi

\begin{tabular}{lcc}
\hline Değişken & $\boldsymbol{n}$ & \% \\
\hline 0 Puan & 10 & 2,6 \\
\hline 1 Puan & 20 & 5,2 \\
\hline 2 Puan & 21 & 5,5 \\
\hline 3 Puan & 117 & 30,5 \\
\hline 4 Puan & 161 & 41,9 \\
\hline 5 Puan & 55 & 14,3 \\
\hline Toplam & $\mathbf{3 8 4}$ & $\mathbf{1 0 0 , 0 0}$ \\
\hline
\end{tabular}

Katılımcıların \% 41,9’u (161 kişi) hastanenin genel hizmet kalitesine 5 üzerinden 4 puan, \% 30,5'i (117 kişi) 3 puan, \% 14,3'ü (55 kişi) 5 puan vermişlerdir. \% 5,5'i (21 kişi) hastanenin genel hizmet kalitesine 5 üzerinden 2 puan, \% 5,2'si (20 kişi) 1 puan, \%2,6's1 (10 kişi) 0 puan vermişlerdir. Katılımcıların \%86'7'si 333 kişinin hastanenin hizmet kalitesinden oldukça memnun oldukları görülmektedir. \%13,3'ü 51 kişinin hastanenin hizmet kalitesinden genel olarak memnun olmadıkları görülmektedir. Özellikle katılımcıların \%2,6'sı 10 kişinin hastanenin hizmet kalitesinden hiç memnun olmadıkları görülmektedir. \%14,3'ü 55 kişinin de hastanenin hizmet kalitesini mükemmel olarak gördükleri görülmektedir. 
Tablo-11: Katılımcıların Hastaneyi Seçme Nedenleri

\begin{tabular}{|c|c|c|c|}
\hline $\begin{array}{l}\text { Önem } \\
\text { Sirast }\end{array}$ & Değişken & $n$ & $\%$ \\
\hline 1. & Bulunduğum yere yakın olması & 211 & 17,2 \\
\hline 2. & Sosyal Güvencesinden Dolayı & 184 & 15,1 \\
\hline 3. & Doktorların Başarıs1 & 156 & 12,7 \\
\hline 4. & Tedavi süreçlerinin Kalitesi & 131 & $\mathbf{1 0 , 7}$ \\
\hline 5. & Sağlık Personelinin Deneyimli Olması & 109 & 8,9 \\
\hline 6. & Teknolojik İmkanları & 106 & 8,6 \\
\hline 7. & Tanıdıkların Tavsiyesi & 105 & 8,5 \\
\hline 8. & Hastanenin Hijyenik Ortamı & 78 & 6,3 \\
\hline 9. & Fiziki Koşulların Rahatlığı & 74 & 6,1 \\
\hline 10. & Personel Kılık Kıyafetinin Düzgün Olması & 64 & 5,2 \\
\hline 11. & $\begin{array}{l}\text { Diğer (Yönlendirme, kaza sonrası mecburiyet, çocuk acilinin } \\
\text { olması, bekleme süresinin k1sa olması, branş doktorunun } \\
\text { tedavisini denemek, gidecek başka hastane olmaması, } \\
\text { profesörler olduğu için) }\end{array}$ & 9 & $\mathbf{0 , 7}$ \\
\hline Toplam & & 1227 & 100,00 \\
\hline
\end{tabular}

Not: n sayısı örneklem hacmini geçmektedir.

Katılımcıların hastaneyi tercih etme nedenleri arasında ilk sırada hastanenin bulundukları yere yakın olması, ikinci sırada sosyal güvencesinden dolayı, üçüncü sırada doktorların başarısı, son sırada ise sırada diğer seçenekler (yönlendirme, kaza sonrası mecburiyet, çocuk acilinin olması, bekleme süresinin kısa olması, branş doktorunun tedavisini denemek, gidecek başka hastane olmaması, profesörlerin olması) yer almaktadır.

\section{TARTIŞMA, SONUÇ VE ÖNERILER}

Elde edilen burgular 1şı̆̆ında kurumsal imajın fiziksel, iletişim, kalite ve sosyal sorumluluk boyutları üzerinden değerlendirilebileceği görülmüştür. Bu sonuç Türkiye' de yapılan ve kurumsal imaj boyutları ve kurumsal imajı açıklayan faktörleri açıklayan bazı araştırmaları (Özata ve Sevinç, 2009; Yeşil, 2016; Yağmuroğlu, 2018 ve Aksoy ve Bayramoğlu, 2008 gibi) doğrular niteliktedir.

Araştırma sonucunda hastanenin kurumsal imajına ilişkin boyutlardan kalite faktörü yüksek düzeyde algılanırken, bunu sırasıyla iletişim, fiziksel ve sosyal sorumluluk faktörü takip etmiştir. Yapılan araştırmalarda kurumsal imajın arttırılmasında kurumun hizmet kalitesinin geliştirilmesi gerektiğine vurgu yapılması, algılanan hizmet kalitesinin kurumsal imaj üzerinde belirleyiciliği ve hastaların sadakat davranışını ve memnuniyetini şekillendirmesi (İzci ve Saydan, 2013; Çetin,2016; Öncü, 2018; Akbolat vd.,2017; Şener, 2014) gibi görüşler ve bu araştırmada ulaşılan sonuç açıkça göstermektedir ki 
kaliteli olmayan sağlık hizmeti kurumsal imaja zarar vermektedir. Bu araştırmada, katılımcılar, kalite boyutu ile ilgili olarak hizmet aldıkları sağlık personelinin alanında deneyimli olduğunu, hasta bilgilerinin gizliliğine özen gösterildiğini, hastanede güncel tanı ve tedavi yöntemlerinin kullanıldığını, hastalıkların tanı ve tedavi sürecinde kullanılan tıbbi ekipmanların yeterli olduğunu, hastanede tıbbi hizmetlerden kolaylıkla yararlanabildiklerini, hastanede hasta kabul işlemlerinin kolaylıkla yapıldığını ve hizmet aldıkları hastane personelinin kişisel hijyen kuralarına özen gösterdiğini düşünmektedirler.

Sağlık iletişimi, sağlık hizmeti alan ve sağlık hizmeti verenler arasında gerçekleşen etkileşimdir. Bu sürecin olumlu gerçekleşmesi hizmet alanların kuruma güvenini, tedavi sürecine bağlığını, hekim ve sağlık tesisine tekrar gelme olasılığını ve genel anlamda memnuniyetini arttırmaktadır (Aydoğan, 2015: 1). Araştırmada katılımcılar, kalite boyutundan sonra en yüksek düzeyde iletişim boyutunu algılamışlardır. Katılımcılar genel olarak kurumsal imaj ölçeğinin iletişim boyutu açısından; hastanedeki sağlık personelinin, sağlık hizmeti alanlarla olumlu iletişim kurduklarını, sağlık personeline gerek duyulduğunda kolay ulaşabildiklerini, hastaneden tedavileriyle ilgili bilgileri kolaylıkla alabildiklerini, hastaneye elektronik ortamda erişimin kolay olduğunu ve sağlık personelinin hastaların sorularına anlaşılır bir şekilde cevap verdiklerini düşünmektedirler.

Katılımcıların hastanenin fiziksel olanakları ile ilgili algıları, kalite ve iletişim boyutlarından daha düşük olduğu belirlenmiştir. Katılımcılar genel olarak kurumsal imaj ölçeğinin fiziksel boyutu açısından; hastanenin isminin hatırlanmasının kolay olduğunu, hastane içindeki yönlendirme tabelalarının yeterli düzeyde yön gösterici olduğunu, hastane binasının ısınma düzeyini yeterli olduğunu ve hastane personelinin dış görünümünün (k1lık, kıyafetini) iyi olduğunu düşünmektedirler. Katılımcılar tarafından fiziksel faktör yetersiz görülen hastane binasının aydınlatması, hastane içerisindeki kantin olanakları, hastane içinde çocuklar için oyun alanları yetersiz bulunmuştur.

Günümüzde önemi her geçen gün artan sosyal sorumluluk kavramı, kurumların marka imajını güçlendirici bir etken olarak görülmektedir. Sağlık kurumları, birey ve toplumun sağlığını korumak ve geliştirmek gibi önemli bir hizmet vermektedir. Ancak günümüz rekabet koşulları sağlık kurumlarına bu hayati görevinin yanı sıra toplum yararına gönüllü 
sosyal sorumluluk faaliyetlerinde bulunmaları gerekliliğini de doğurmuştur. Katılımcılar genel olarak kurumsal imaj ölçeğinin sosyal sorumluluk boyutu altındaki sorulara verdikleri cevaplarda kararsız bir tutum sergilemişlerdir. Kurumsal imaj alt boyutu olan sosyal sorumluluğa bakış açısı noktasında Düzce içerisinde ikamet edenlere oranla Düzce dışında ikamet edenlerin hastanenin daha fazla sosyal sorumluluğa sahip olduğunu düşünmektedirler. Hastanenin sosyal sorumluluk faaliyetleri hayata geçirmesi ve bu faaliyetleri toplumun öğrenmesi açısından medya, halkla ilişkiler gibi çeşitli araçlarla duyurulması sağlanmalıdır.

Katılımcıların hastaneyi tercih etme nedenlerinden ilk beş sıraya bakıldığında; ilk sırada hastanenin bulundukları yere yakın olması, ikinci sırada bağlı olduğu sosyal güvenlik kurumu gelmektedir. Kamu hastanesi olması ve özellikli branşları bünyesinde barındırması, hastaların il dışındaki hastanelere ihtiyacını azaltarak daha çok kendi ilindeki hastaneyi tercih ettiklerini göstermektedir. Katılımcılar hastaneyi tercih nedenleri arasında üçüncü sırada doktorların başarısını gelmiştir. Laohasirichaikul ve arkadaşları (2011) yaptıkları araştırma sonuçları müşteri memnuniyetini ve müşteri sadakatini etkileyen en önemli faktörün 'doktor endişesi' olduğunu ve kurumsal imaj1 etkileyen en önemli ikinci faktör olduğunu göstermiştir.

Araştırmada elde edilen bulgulara dayalı olarak şu öneriler sunulmuştur:

- Kalite boyutuna ilişkin sonuçlardan hareketle sağlık kurumlarına tanı ve tedavi süreçleri, ekipman ve personel kalitesi üzerinde durması önerilir.

- Hasta-sağlık çalışanı iletişim kalitesinin artırılması açısından periyodik olarak sağlık çalışanlarına sağlık iletişimi konusunda eğitim verilmesi önerilir.

- Sağlık kurumlarında aydınlatma, kantin olanakları, çocuklar için yeterli düzeyde oyun alanları ile ilgili iyileştirmeler yapılması önerilir.

- $\quad$ Çevre sağlığına dost, toplum sağlığını koruyucu, bilgilendirici ve farkındalık oluşturacak faaliyetlere ağırlık vermesi kurum imajının artmasına katkı sağlayabilir.

- Kurumsal imaj oluşturmada halkla ilişkiler ve kalite yönetim birimlerinin yapısı güçlendirilmesi önerilir. 
- İleride yapılacak araştırmalara sağlık hizmeti sunan kamu ve özel hastaneler arasında karşılaştırmalı çalışmalar yürütülmesi ve kurumsal imaj ve sağlık kurumunun performansı arasındaki ilişkilerin incelenmesi önerilir. 


\section{KAYNAKÇA}

Adenike, A. A. Omotayo, A. O. Joachim, A. \& Ojo, O. E. (2015), Corporate Image: A Strategy for Enhancing Customer Loyalty and Profitability, Journal of South African Business Research, 1-12. https://ibimapublishing.com/articles/JSABR/2015/259483/259483.pdf

Ak, M. (1998), Firma/markalarda Kurumsal Kimlik ve Imaj. İstanbul: Kendi Yayın.

Akbolat, M., Durmuş, A., Ünal, Ö., Amarat, M. \& Fazla, İ. (2017). Hastaların Kurumsal İmaj Algılarının Hastane Bağlılıklarına Etkisi, European Journal of Educational

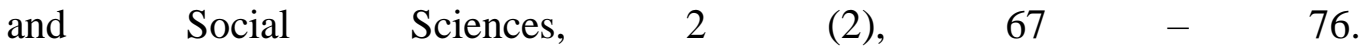
https://dergipark.org.tr/tr/pub/ejees/issue/39108/459159

Akbulut, B. (2015). Ortaöğretim Kurumlarında Görev Yapan Öğretmenlerin Örgütsel İmaj Algıları İle İş Doyumu Düzeyleri Arasındaki İlişki. Doktora Tezi, Hacettepe Üniversitesi, Eğitim Bilimleri Enstitüsü, Ankara.

Akdur, R. (1999). Türkiye'de Sağlık Hizmetleri ve Avrupa Topluluğu Ülkeleri ile Kıyaslanması. A.Ü.T.F Halk Sağlığı Anabilim Dalı, Ankara, 1999. https://www.recepakdur.com/media/1720/turkiye-de-saglik-hizmetleri-veavrupa-toplulugu-ulkeleri-ile-kiyaslanmasi.pdf (Erişim Tarihi 25.09.2019).

Akıncı Vural, Z. B. \& Bat, M. (2013). Kurumsal İletişim Teoriden Pratiğe, İstanbul: İletişim Yayınları.

Aksoy R. \& Bayramoğlu, V. (2008). Sağlık İşletmeleri İçin Kurumsal İmajın Temel Belirleyicileri: Tüketici Değerlemeleri, ZKÜ Sosyal Bilimler Dergisi, 4 (7), 8596. https://dergipark.org.tr/en/download/article-file/1145030

Amini, A., Darani, M., Afshani, M., \& Amini, Z. (2012). Effectiveness of Marketing Strategies and Corporate Image on Brand Equity as a Sustainable Competitive Advantage, Interdisciplinary Journal Of Contemporary Research In Business, 4 (2), 192-205. https://journal-archieves19.webs.com/192-205.pdf

Aydoğan, M. (2015). Sağlık Hizmetlerinin Gelişimi ve Sağlık Hizmetleri Sunumunda İletişimin Önemi. Yüksek Lisans Tezi, Beykent Üniversitesi Sosyal Bilimler Enstitüsü, İstanbul.

Bankaoğlu, E. (2013). Hasta Memnuniyetinin Kurumsal İmaj Üzerindeki Etkisi: Antalya Eğitim ve Araştırma Hastanesi Üzerine Bir Araştırma. Yüksek Lisans Tezi, Akdeniz Üniversitesi Sosyal Bilimler Enstitüsü, Antalya.

Bathmanathan, V. \& Hironaka, C. (2016). Sustainability And Business: What İs Green Corporate İmage?. IOP Conference Series: Earth and Environmental Science, 32 (1)., 1-4. https://iopscience.iop.org/article/10.1088/1755-1315/32/1/012049/pdf 
Bayın, G. (2013). Hastanelerde Kurumsal İmaj ve Hasta Bağlılığı İlişkisi: Ankara Eğitim Ve Araştırma Hastanesi İle İbni Sina Hastanesi'nde Bir Uygulama, Yüksek Lisans Tezi, Ankara Üniversitesi Sağlık Bilimleri Enstitüsü, Ankara.

Bayramoğlu, V. (2007). Sağlık İşletmeleri İçin Kurumsal İmajın Temel Belirleyicileri: Zonguldak Örneği. Zonguldak Karaelmas Üniversitesi Sosyal Bilimler Enstitüsü, Yayınlanmamış Yüksek Lisans Tezi, Zonguldak.

Bektaş, Ö. (2015). Sağlık İşletmelerinde Kurumsal İmajı Belirleyen Faktörler (Rize Devlet Hastanesi Örneği). Yüksek Lisans Tezi, Beykent Üniversitesi Sosyal Bilimler Enstitüsü, İstanbul.

Bhatti, I. M. \& Awan, M.H (2017). Impact Of Corporate Iamge On The Use Of Bank Service: A Case Of Conventional vs. Islamic Banks Marketıng, Annales Universitatis Apulensis Series Oeconomica, $19 \quad$ (1), 25-45. http://www.oeconomica.uab.ro/upload/lucrari/1920171/02.pdf

Bıçakçı, B. A. (2011). Halkla İlişkilerde Kurumsal Sosyal Sorumluluk Algısının Ölçümü, Global Media Journal Turkish Edition, 1 (2), 1-30. https://globalmediajournaltr.yeditepe.edu.tr/sites/default/files/Ays\%CC\%A7e\%2 0Banu\%20BIC\%CC\%A7AKC\%CC\%A7I.pdf

Bilgin, L. (2010). Halkla İlişkiler. İstanbul: Kumsaati yayın.

Bolat, İ. O. (2006). Konaklama İşletmelerinde İşgörenlerden Yansıyan Kurumsal İmajın Analizi ve Bir Uygulama. Yayımlanmamış Doktora Tezi, Balıkesir Üniversitesi Sosyal Bilimler Enstitüsü, Balıkesir.

Bouchet, D. (2014). What is "Corporate Image" and "Corporate Identity" -and why do people talk so much about it? , Department of Marketing University of Southern Denmark. https://www.presentica.com/doc/11976156/what-is-corporate-imageand-corporate-identity-and-why-do-people (Erişim Tarihi: 27.11.2021)

Bromley, D. B. (2000). Psychological Aspects of Corporate Identity, Image and Reputation, Corporate Reputation Review, 3 (3), 240-252. https://doi.org/10.1057/palgrave.crr.1540117

Cingöz, A. \& Akdoğan, A. (2011). İşletmelerin Kurumsal Sosyal Sorumluluk Faaliyetleri: Kayseri İli'nde Bir Uygulama, Atatürk Üniversitesi Sosyal Bilimler $\begin{array}{llll}\text { Enstitüsü } \quad \text { Dergisi, } & 16 & \text { 331-349. }\end{array}$ https://www.acarindex.com/dosyalar/makale/acarindex-1423871436.pdf

Çerik, Ş. \& Erkmen, T. (2006). Kurum İmajını Etkileyen Faktörlerin Algılanması ve Bu Algılamaların Beklentilerle Karşılaştırılması: Üniversite Öğrencilerine Yönelik Bir Araştırma, Mustafa Kemal Üniversitesi Sosyal Bilimler Enstitüsü Dergisi, 3 (6), 331-339. https://dergipark.org.tr/en/pub/ataunisosbil/issue/2831/38464 
Çetin, B. (2016). Kurumsal İmajın ve Algılanan Hizmet Kalitesinin Hasta Sadakati Üzerine Etkisi. Yüksek Lisans Tezi, Bahçeşehir Üniversitesi Sağlık Bilimler Enstitüsü, İstanbul.

Çorakçı, A. Ö. (2007). İnsan Kaynakları Yönetiminde Eğitimin Kurum İmajının Sürekliliğinin Sağlanmasındaki Rolü ve Bir Uygulama. Yayımlanmamış Yüksek Lisans Tezi, Marmara Üniversitesi Sosyal Bilimler Enstitüsü, İstanbul.

Deniz, S. \& Yüksel, O. (2018). Sağl1k Tüketicilerinin Kurumsal İmaj Algııı İle Hastane Bağlılığı Arasındaki İlişkinin Belirlenmesine Yönelik Bir Araştırma, Avrasya

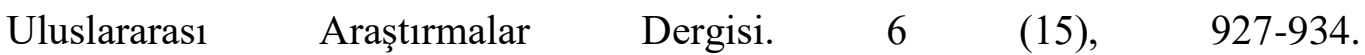
https://doi.org/10.33692/avrasyad.510401

DGH (2019). "Sağlık Turizmi Kazandırıyor" https://www.dunyagoz.com/tr/kurumsal/basinda-biz/saglik-turizmi-kazandiriyorborsaci.

Emül, B. \& Naldöken, Ü. (2019). Sağlık Kurumlarında Kurumsal İmajın Hasta Memnuniyetine Etkileri, Hacettepe Sağlık İdaresi Dergisi, 22 (2), 359-374. https://dergipark.org.tr/tr/pub/hacettepesid/issue/48866/622759

Emül, B. (2018). Sağlık Kurumlarında Kurumsal İmajın Hasta Memnuniyetine Etkilerinin Belirlenmesine Yönelik Bir Alan Araştırması, Yüksek Lisans Tezi, Sivas Cumhuriyet Üniversitesi Sağlık Bilimleri Enstitüsü, Sivas.

Erdoğan, Y., Bayram, S. \& Deniz, L. (2007), Web Tabanlı Öğretim Tutum Ölçeği: Açıklayıcı ve Doğrulayıcı Faktör Analizi Çalışması, İnsan Bilimleri Dergisi, 4 (2) , 1-14. https://core.ac.uk/download/pdf/268072138.pdf

Gray E. R. \& Balmer, J. M. T (1998). Managing Corporate Image and Corporate Reputation, European Journal of Marketing, 31 (5), 649-802. https://doi.org/10.1016/S0024-6301(98)00074-0

Gümüş, M. (1995). Yönetimde Başarı İçin Altın Kurallar, İstanbul: Alfa.

Gürbüz, S. (2017). Kurum İmajı Bileşenleri ve Belirleyicileri. İstanbul: Literatürk Academia.

Gürgen, H. (1990). Reklamcılık ve Metin Yazarlı̆̆ı. Eskişehir: Anadolu Üniversitesi Açık Öğretim Fakültesi Yayınları.

Han, W. J. (2006). The Impact of Self-Concept/Product-Image Congruity and Functional Congruity on Brand Preference: Three Product Categories, (Unpublished Doctoral Dissertation) The Florida State University. USA

Howard, S. (1998). Corporate Image Management. Singapore: Butterworth-Hienemann.

Hsieh, M. H., Pan, S. L., \& Setiono, R. (2004) Product-, Corporate-, and Country-Image Dimensions and Purchase Behavior: A Multicountry Analysis, Academy of 
Marketing Science, $\quad 32 \quad$ (3),

https://link.springer.com/article/10.1177/0092070304264262

İzci, F. \& Saydan, R. (2013). Algılanan Hizmet Kalitesi Kurumsal İmaj ve Sadakat İlişkisi (Van Bölge Hastanesi Uygulaması). Cumhuriyet Üniversitesi İktisadi ve İdari Bilimler Dergisi, $\quad 14 \quad$ 199-219. https://kutuphane.dogus.edu.tr/mvt/pdf.php?pdf=0018253\&lng=0

Kalaycı, S. (2004). Ülke İmajı Ve Marka İmajı Etkilerinin Satın Alma Kararları Üzerine Etkisi, Yüksek Lisans Tezi, Gazi Üniversitesi İşletme Anabilim Dalı, Ankara.

Karasar, N. (1999). Bilimsel Araştırma Yöntemi. Ankara: Nobel Yayınevi.

Karyose, H., Astuti, W. \& Ferdiansjah, A. (2017). Customer Loyalty: The Effect of Service Quality, Corporate Image, Customer Relationship Marketing and Customer Satisfaction as Intervening Variable-An Empirical Analysis of Bank Customers in Malang City, Marketing and Branding Research, 4, 336-347. https://mbr.cikd.ca/article_60334.html

Keller, K. L. (1998). Strategic Brand Management: Building, Measuring and Managing Brand Equit. U.S.A: Prentice Hall.

Kim, E.C., Shin, J., Lee, J., Lee Y.J., Kim, M., Choi, A., Park, K., Lee, H. \& Ha, I. (2017). Quality of medical service, patient satisfaction and loyalty with a focus on interpersonal-based medical service encounters and treatment effectiveness: a cross-sectional multicenter study of complementary and alternative medicine

(CAM) hospitals. BMC Complement Altern Med., 17(1), 174. https://bmccomplementmedtherapies.biomedcentral.com/articles/10.1186/s1290 6-017-1691-6

Koçyiğit, M., Koçyiğit, A. \& Özel, G. (2018). Kurumsal Sosyal Sorumluluk Algısının Tüketici Temelli Marka Değeri Üzerindeki Etkisini Ölçmeye Yönelik Bir Araştırma, Manas Sosyal Araştırmalar Dergisi, 7 (4), 267-286. https://dergipark.org.tr/tr/pub/mjss/issue/43010/520781

Kolade, O. J., Oluseye, O.O. \& Omotayo, A. O. (2014). Organizational Citizenship Behaviour, Hospital Corporate Image and Performance. Journal of Competitiveness, Journal of Competitiveness, 6 (1), 36-49. http://dx.doi.org/10.2139/ssrn.304786

Korkmaz, S. \& Çuhadar, U. (2017). Sağlık Hizmet Kalitesi ve Sağlık Kurumunu Tekrar Tercih Etme Niyeti Arasındaki İlişki: Eğitim ve Araştırma Hastanesi Örneği, Uluslararası Sağlık Yönetimi ve Stratejileri Araştırma Dergisi, 3 (1), 72-87. https://dergipark.org.tr/tr/download/article-file/298214

Laohasirichaikul, B., Chaipoopirutana, S. \& Combs, H. (2011). Effective Costumer Relationship Management of Health Care: A Study of Hospitals in Thailand, Journal of Management and Marketing Research, 6, 1-12. 
https://scholarworks.sjsu.edu/cgi/viewcontent.cgi?referer=\&httpsredir=1\&article $=1001 \&$ context $=$ mktds_pub

Nguyen, N. \& Leblanc, G., (2001). Corporate Image And Corporate Reputation In Customers' Retention Decisions In Services, Journal Of Retailing And Consumer Services. 8, 227-236. https://doi.org/10.1016/S0969-6989(00)00029-1

Okay, A. (2008). Kurum Kimliği, İstanbul: MediCat Kitapları.

Okoisama, C. T., Best, C. E. \& Anyanwu, A. S. (2017). Corporate Image Management And Firm's Competitive Advantage: A Study Of The Telecommunication Industry In Port Harcourt, International Journal of Advanced Academic Research Social \& Management Sciences, 3 (6), 16-31. https://ijaar.org/articles/Volume3Number6/Social-Management-Sciences/ijaar-sms-v3n5-may17-p11.pdf

Öncü, D. (2018). Hastaların Hastane Hizmet Kalitesine Yönelik Algılarının Hastane Kurumsal İmajı Üzerindeki Etkileri. Yüksek Lisans Tezi, Maltepe Üniversitesi Sosyal Bilimler Enstitüsü, İstanbul.

Özata, M. \& Sevinç İ. (2009). Hastanelerde Kurumsal İmajın Ölçülmesinde Dikkate Alınması Gereken Faktörlerin Belirlenmesi, Journal of Azerbaijani Studies, 5974.

http://jhss-khazar.org/2009-122/HASTANELERDE\%20KURUMSAL\%20IMAJIN\%20OLCULMESINDE\%2 0DIKKATE\%20ALINMASI\%20GEREKEN\%20FAKTORLERIN\%20BELIRL ENMESI.pdf

Özen, Y. \& Gül, A. (2007), Sosyal ve Eğitim Bilimleri Araştırmalarında Evren· Örneklem Sorunu, Atatürk Üniversitesi Kazım Karabekir Eğitim Fakültesi $\begin{array}{llll}\text { Dergisi, } & 15, & 394 & -\end{array}$ https://dergipark.org.tr/tr/pub/ataunikkefd/issue/2776/37227

Polat, S. \& Arslan Y. (2015). Örgütsel Yaşamda İmaj: Imaj Geliştirme ve Yönetimi, (1 Baskl). Ankara: Nobel kitap.

Riordan, C.M., Gatewood, R. D. \& Bill, J. B. (1997). Corporate Image: Employee Reactions and Implications for Managing Corporate Social Performance. Kluwer Academic Publishers, Journal of Business Ethics 16: 401-412. https://link.springer.com/article/10.1023/A:1017989205184

Sallam, A. M. (2016). The Impact of Brand Image and Corporate Branding on Consumer's Choice: The Role of Brand Equity, International Journal of $\begin{array}{lllll}\text { Marketing } & \text { Studies, } & 8 & \text { (1), }\end{array}$ https://www.ccsenet.org/journal/index.php/ijms/article/view/56928

Şener, H. Y. (2014) Improving Patient Satisfaction in Health Services: An Application At Dumlupinar University Kutahya Evliya Celebi Education \& Research Hospital. European Journal of Business and Management 6 (30) : 172-181. https://www.iiste.org/Journals/index.php/EJBM/article/view/15635 
Tran, M., Nguyen, B., Melewar, T. \& Bodoh, J. (2015). Exploring the corporate image formation process, Qualitative Market Research, 18 (1), 86-114. https://doi.org/10.1108/QMR-05-2014-0046

Turgut, A. (2003). Hastanelerde İmaj ve İmaj Geliştirme: Toplumda Hastane İmajı Tespiti ve İmaj Geliştirme Üzerine Bir Çalışma. Yüksek Lisans Tezi, Gazi Üniversitesi Sosyal Bilimler Enstitüsü, Ankara.

Upamannyu, K. N., Bhakar, S. S. \& Gupta, M. (2015). 'Effect of Corporate Image on Brand Trust and Brand Affect, International Journal of Applied Science-Research and Review (IJAS), 20-33. https://www.researchgate.net/publication/272892601_Effect_of_Corporate_Ima ge_on_Brand_Trust_and_Brand_Affect

Ün, H. (2016), Sosyal Medyada Türkiye İmajı: Youtube Video Bloglarında Türkiye İmajı Üzerine Bir İnceleme, Yüksek Lisans Tezi. Atatürk Üniversitesi Sosyal Bilimler Enstitüsü, Erzurum.

Van Riel, C. B. \& Fomburn C. J., (2007). Essentials of Corporate Communications: Implementing Practices for Effective Reputation Management, New York: Routledge Publishing.

Wu, C. (2011). “The Impact of Hospital Brand Image on Service Quality, Patient Satisfaction And Loyalty", African Journal of Business Management, Vol: 5, No: 12, 4873-4882. https://doi.org/10.5897/AJBM10.1347

Yağmuroğlu, B. (2018). Tüketicilerin Sağlık İşletmelerinin Kurumsal İmajına Yönelik Algılamaları-Aydın İlinde Bir Uygulama, Yüksek Lisans Tezi, Adnan Menderes Üniversitesi Sosyal Bilimler Enstitüsü, Aydın.

Yanık, A. (2000). Sağlık Bakım Hizmetlerinde Hasta Tatmini ve Haydarpaşa Numune Eğitim ve Araştırma Hastanesi’nde Hasta Tatmini Üzerine Bir Araştırma. Doktora Tezi. Marmara Üniversitesi Sosyal Bilimler Enstitüsü, İstanbul.

Yeşil, A. (2016). Sağlık Hizmeti Kullanıcılarının Hastanelerle İlgili Kurumsal İmaj Algılarını Etkileyen Faktörler Üzerine Bir Araştırma. Yüksek Lisans Tezi, Mehmet Akif Ersoy Üniversitesi Sosyal Bilimler Enstitüsü, Burdur.

Yücel, A \& Yücel, N. (2012). Mağaza İmajı ile Mağaza Sadakati Arasındaki İlişkinin Belirlenmesi: Denizli İlinde Yapılan Bir Araştırma, Yönetim Bilimleri Dergisi 10 (9), 100. https://dergipark.org.tr/tr/download/article-file/46296

Yüksel, N. (2015). Türkiye'de Sağlık Sistemi ve 2003 Y1lında Yapılan Sağlıkta Dönüşüm Reformunun Olumlu ve Olumsuz Algılarının Ölçümü Yüksek Lisans Tezi, İstanbul Üniversitesi Sağlık Bilimleri Enstitüsü, İstanbul. 